\title{
Learning Environmental Ethics from Sebuah Wilayah yang Tidak Ada di Google Earth by Pandu Hamzah
}

\author{
Rahastri Fajar Puspasari \& Wiyatmi \\ rahastrifajar@gmail.com,wiyatmi@uny.ac.id \\ Indonesian Literature Study Program, Faculty of Languages and Arts \\ Universitas Negeri Yogyakarta, Indonesia
}

\begin{abstract}
This study aims to describe (1) the manifestations of environmental wisdom and (2) the role of the characters in environmental preservation contained in the novel Sebuah Wilayah yang Tidak Ada di Google Earth by Pandu Hamzah. This research is included in the type of descriptive qualitative research. The data source of this research is the novel Sebuah Wilayah yang Tidak Ada di Google Earth by Pandu Hamzah published by Literati in 2015. This research is focused on the manifestation of environmental wisdom and the role of characters in the novel by using ecocritical analysis. The data collection techniques are the technique of reading and taking notes. The data analysis technique used is descriptive qualitative. The validity of the data is obtained through semantic validity and intrarater reliability tests. The data were analyzed with description, categorization, and data presentation. The results of the study indicate the following matters. First, the manifestation of environmental wisdom found in the novel includes nine principles of environmental ethics, including (1) respect for nature; (2) the attitude of responsibility towards nature; (3) cosmic solidarity; (4) the principle of compassion and care for nature; (5) the principle of no harm; (6) the principle of living simply and in harmony with nature; (7) the principle of justice; (8) democratic principles; and (9) the principle of moral integrity. Among these principles, the most dominant principle is the principle of respect for nature. Second, the role of the characters in environmental preservation contained in the novel is divided into two categories, namely the role of pro-environment and non pro-environment.
\end{abstract}

Keywords: environmental wisdom, environmentalism, eco-criticism

\section{Introduction}

Nowadays our environment is in crisis and broken everywhere. It is not only physical environment crisis, such as water, soil, air, and climate crisis but also biological environmental and social environmental crisis. The root of the problem stems from the environmental damage caused by human behaviour in an effort to meet the needs of economic life that does not pay attention to environmental balance (Susilo, 2012, p. 19).

According to Arne Naess (via Keraf, 2010, p. 2), today's environmental crisis can only be overcome by making fundamental and radical changes in human outlook and behaviour towards nature. It takes environmental ethics that guide humans to interact newly in the universe. Human awareness to be ethical with the environment has been carried out by several communities of nature lovers, environmental activists, and the government, although not yet fully. One of them like the Ministry of Environment and Forestry (KLHK) in the National Priority Lake Rescue Coordination Meeting and the Revitalization of the Lake Rescue Movement (menlhk.go.id) states that KLHK continues to intensify efforts to save lakes, especially for 15 priority lakes 
that have damaged conditions or threatened. One of the efforts is through strengthening the synergy of lake management between the parties.

Indirectly, literature has also taken part in building changes in the way of readers reading about the environment through literary works, especially the genre of green literature. Green literature is a genre of literary works that has several criteria, namely the language used contains a lot of ecological diction. The content of the work is based on a sense of love for the earth. They are the pain of the broken earth, the expression of anxiety in responding to the destruction of the earth, fighting injustice over the arbitrary treatment of the earth and its contents (trees, mines, water and air, as well as its inhabitants-humans), the idea of liberating the earth from destruction, and its implementation. Green literature must be able to influence people's mind sets and attitudes towards the destruction of earth. This is in accordance with the vision and mission of green literature, namely literature that plays a role in awareness and enlightenment that is expected to change the lifestyle of the destroyer into a preserver who cares for the earth (go green) (Pranoto, 2014, p. 5). In addition to developing green literature, which is not less important is also developing literary criticism with ecological insight, known as eco-criticism or ecofeminism (Warren, 2011; Wiyatmi, 2019, p. 17; Sukmawan, 2015, p. vi).

One of the green literary works that takes up environmental themes is a novel entitled Sebuah Wilayah yang Tidak Ada Di Google Earth (2015) by Pandu Hamzah. The uniqueness of this novel is that the characters in the novel by Pandu Hamzah do not only involve humans as characters to protect the environment, but also involve the role of animals, plants, creatures that exist between, and not (Ulu-ulu). The figures are The Tree-Cutting Man, Rama Djati Kusuma, The Black (children), Mak Laksi (30s), Octaviany Kiara (20s), Kinanti (Ms. Kiara), Chevron, Government, "Ajag" girl (coyote) incarnation, Zasu (Ulu-ulu creature), Angel of Happiness, Mother of Walik Bird, and Kiara tree.
Environmental problems in the novel Sebuah Wilayah yang Tidak Ada Di Google Earth is not only about the felling of Kiara tree which is the source of water in the area but also about the changing status of Mount Ciremai to Mount Ciremai National Park and Chevron's plan to exploit the geothermal Mount Ciremai. The leaders then made various efforts to continue to protect the environmental area on Mount Ciremai. Ciremai Mountain is one of Mount Ceremai Mountains which is the highest mountain $(3,078 \mathrm{~m})$ in West Java Province, precisely in Kuningan Regency and Majalengka Regency. Mount Ceremai area has the potential of abundant natural resources, including biological resources, land resources, and water sources. While the functions of Mount Ceremai area include are (a) for education, (b) vehicle for tourism, (c) catchment area, (d) buffer area, (e) water source, and (f) agriculture, forestry, and plantation cultivation (Alviya, 2006, p. 88).

Based on the description above, it is necessary to do research on the form of environmental wisdom carried out by the characters in Sebuah Wilayah yang Tidak Ada Di Google Earth by Pandu Hamzah along with the role of the characters in environmental preservation contained in the novel that can be a lesson in environmental ethics for the reader.

\section{Methodology}

This research is a qualitative descriptive study using ecocritical theory. Qualitative research, as a research procedure, produces descriptive data that leads to the form of environmental wisdom and the role of the characters. Both data contained in Sebuah Wilayah yang Tidak Ada di Google Earth. The primary datum in this study is from the novel Sebuah Wilayah yang Tidak Ada di Google Earth by Pandu Hamzah published by Literati in April 2015. The secondary data are the background information on Pandu Hamzah novel Sebuah Wilayah yang Tidak Ada di Google Earth, environmental issues rose in the novel, and environmental research relevant to the topic of discussion.

The data in this research are in the form of words, phrases, clauses, sentences, and 
discourse from Sebuah Wilayah yang Tidak Ada di Google Earth which contains information related to the form of environmental wisdom and the role of the characters in environmental preservation contained in the novel. The techniques of obtaining data used in this study are reading and recording. The researchers read the data repeatedly then take notes some information relating to the formulation of the problem. The researchers also made a marking on the data that shows the existence of environmental wisdom and the role of the characters in environmental care contained in Sebuah Wilayahyang Tidak Ada di Google Earth.

The data analysis technique in this study was a qualitative descriptive technique. It was also carried out in a description, in which the researchers grouped the data according to certain characteristics and categories. There is also a tabulation data from the data form, for example the researchers present the data in tabular form as a result of the categorization of each research objective. Then, the data that has been obtained are analysed in accordance with ecocritical theories to describe the environmental wisdom and the role of the characters in environmental preservation contained in Sebuah Wilayah yang Tidak Ada di Google Earth.

The instrument used in this study was the researchers themselves (human instrument). Researchers who carry out all activities, ranging from planning, implementing data collection, analysis, interpretation of data, and reporting the results of research. Logic and interpretative abilities of researchers are used as a basis for conducting analysis. In this study, researchers used semantic validity and referential validity. Semantic validity is used to examine and measure the validity of data relevant to the context of the story, while referential validity is used to ensure the validity of data and understanding based on the reference libraries used. The reliability used in this study is intrarater reliability. This reliability is done by reading and understanding the study material critically and repeatedly until consistent data is obtained.

\section{Findings and Discussion}

Based on research that has been done, the researchers found nine forms of environmental wisdom in the novel, such as (1) respect for nature (48 data); (2) attitude of responsibility towards nature (8 data); (3) cosmic solidarity (22 data); (4) the principle of compassion and care for nature (17 data); (5) no harm principle (5 data); (6) the principle of living simply and in harmony with nature (6 data); (7) the principle of justice (2 data); (8) democratic principles (2 data); (9) the principle of moral integrity (2 data). In addition, the characters involved in this story fall into two categories, namely environmental saviours and environmental destroyers facing each other

\section{The Form of Environmental Wisdom in Sebuah Wilayah yang Tidak Ada di Google Earth by Pandu Hamzah}

\section{Respect towards Nature}

The most common form of wisdom found in novel is respect for nature. According to Keraf (2010, p. 167), respect for nature is a basic principle for humans as part of the universe. This attitude is the basis of all other forms of environmental wisdom because this attitude manifests human consciousness to respect the right of all living things to be, live, grow, and develop naturally in accordance with the purpose of its creator.

The awareness was found to begin with the emergence of various principles that underlie the behaviour of the figures that nature and humans have a relationship with each other as an ecological community.

Kalau dari kiai, aku mengenal istilah habluminallah (berkasih sayang dengan Allah) serta habluminannas (berkasih sayang dengan manusia), dari Rama Djati, aku mengenal istilah tambahan yaitu habluminallam; berkasih sayang dengan alam (Hamzah, 2015, p. 41).

The principles embedded in Rama Djati become the basis for good behaviour towards 
the environment, so that a deep love for the environment appears. The principle was eventually transmitted to the people around and one of them was the Tree-Cutting Man.

\section{Principle of Responsibility}

Associated with the principle of respect for nature is a moral responsibility to nature. It is because ontologically humans are an integral part of nature. This fact gave birth to a moral principle that humans actually have the responsibility for the universe and its integrity, as well as for the existence and preservation of every part and object in the universe, especially living things (Keraf, 2010, p. 169).

In the novel, the principle of responsibility is shown by The Tree-Cutting Man. The guilty feeling of cutting down the Kiara tree continues to haunt the Tree-Cutting Man. The reason is, a week after felling the tree, the spring there dried up. He also had appeared Ulu-ulu, which is believed by the public that Ulu-ulu will appear to someone who has made mistakes in nature.

Aku ingin melalui malam ini dengan tenang, meski hati kecilku juga siap andaikata ada perkembangan-perkembangan yang bisa memberiku pencerahan mengenai segala hal yang sudah sebulan lebih ini aku gelisahkan, terutama mengenai Ulu-Ulu atau apa pun itu, dan juga mengenai dosa yang terus tertorehkan di hatiku karena menebang Pohon Kiara Raksasa itu (Hamzah, 2015, p. 80).

Since he felt guilty, the Tree-Cutting Man was finally compelled to repair the damage he had done. In the climb to Mount Cierami, he was met by Black, Ajag Girl, Sazu, and Kiara. That night, in the Forest, they talked about the Prohibition of the Princess Geger and decided to replant the Kiara tree. The meeting seemed to provide an opportunity for the Tree-Cutting Man to restore the ecosystem that had been chaotic due to the removal of the Kiara Tree.

\section{Cosmic Solidarity}

In the perspective of ecofeminism, humans have an equal position with nature and all other living things in this world. This fact arouses human's feeling of solidarity, continuity with nature, and with other fellow living beings. Humans can then feel sad and sick when facing the heart-breaking reality of the destruction and extinction of certain living things (Keraf, 2010, p. 171). In the novel, Ajag Girl who is an incarnations of a coyote along with other coyotes feel a deep sadness after the Kiara tree was cut down.

"Kecewa sekali kami, seluruh penghuni
Desa Ajag berduyun-duyun melihat seolah
tak percaya Pohon Kiara telah tiada. Semua
menangis. Semua hatinya pilu. Termasuk
aku. Bahkan aku tak mau diajak pulang
oleh mereka ke desa kami. Aku bertekad
untuk berusaha menumbuhkan lagi Pohon
Kiara di dekat mata air. Dan aku tak akan
pulang ke desaku sebelum itu terwujud!"
celoteh Gadis Ajag panjang lebar (Hamzah,
2015, p. 138).

The sadness arises because the Kiara tree has its own meaning for the Ajag. Kiara trees have a role in the survival of coyotes. Then came the sense of continuity that the residents of Ajag Village felt, so that there was an urge to save the environment. As the Ajag Girl did, she was determined not to return if she hadn't succeeded in growing the Kiara Tree again. This is in line with Keraf's statement (2010, pp. 171172), that the principle of cosmic solidarity can encourage humans to save the environment, to save all life in nature because nature and all life in it has the same value as human life.

\section{The Principle of Compassion and Concern for Nature}

Compassion and care for nature are based on the awareness that all living things have (1) the right to be protected, (2) the right to be cared for, (3) the right not to be hurt, and (4) protection and maintenance which are done without expecting anything in return (Sukmawan, 2016, p. 24). The memories of each character towards the Kiara tree create a 
sense of affection. The Tree-Cutting Man takes care of the Kiara tree bonsai because of the feeling of losing his brother. For Si Hitam, the Kiara Tree is his escape place if he is scolded by Mak Lasmi.

Semua berlangsung lama. Terasa begitu lama sampai kemudian Emak berhenti sendiri, terduduk di sudut dipan. Sekarang justru dia menangis tersedu-sedu, menutupkan kedua tangan pada wajahnya. Seperti biasa, kalau sudah begitu Emak akan berlama-lama menangis. Aku pun perlahan pergi menuju tempat pelarianku di dekat lembah Cilengkrang. Di sana ada Pohon Kiara dan di dekatnya ada mata air sejuk tempatku biasa berkumur-kumur membersihkan darah dan luka (Hamzah, 2015, p. 100).

Once, Si Hitam met an Ajag girl who was crying near the stump of the Kiara Tree. Ajag girl feels lost the place to play after the Kiara Tree was cut down for the benefit of the group.

"Hei, kenapa menangis? Hei!"

Dia menoleh menatapku sejenak, kemudian tangannya menunjuk pada mata air. "Mata airnya kering, mereka menebang Pohon Kiara, maka mata air ini jadi kering, aku tak bisa bermain-main lagi di sini!" (Hamzah, 2015, p. 101).

The figure of Kiara also has a bond with the Kiara Tree. Her ancestors who had been covered up by his mother turned out to be buried near the Kiara Tree. The truth was that Kiara learned after her meeting with Zasu.

These engagements eventually led the leaders to restore the existence of the Kiara Tree that had been cut down. Through the journey made by Si Hitam and Ajag girls to find ways how to plant Kiara Trees, one by one they finally met.

Kiara Tree Bonsai, which has been cared for by Tree-Cutting Men, has been a saviour of their memories. Kiara tree is a tree that is difficult to plant because the process of planting cannot come from seedlings, but with the intermediary feces of Walik Bird. The meeting in the Forest of the Prohibition of the
Princess Geger became the unifier of their goal to restore the Kiara Tree which was the source of their spring and happiness.

\section{No Harm Principle}

According to Keraf (2010, p. 174), the minimum form that humans can take in protecting nature is not to do actions that harm or threaten the existence of other living things in the universe (no harm). In indigenous communities, this minimum obligation is usually maintained and lived through taboos. Taboo is the myth believed by the public. The novel also exposes the myth believed by the public. Around Mount Ciremai, there is a myth about Ulu-ulu which is believed to be a supernatural creature that controls water. Not everyone can see Ulu-ulu because it will appear only to people who have made mistakes to nature, especially those related to water.

"Kalau menurut almarhum kakekmu
sendiri, Abah Dhamil, Ulu-ulu itu justru
datang pada orang yang sudah melakukan
dosa atau kesalahan sangatbesar dan fatal.
Misalkan kalau ada pendaki yang sompral,
berkata sembarangan, melanggar
pantangan hutan dan sebagainya, dia suka
didatangi Ulu-ulu..." (Hamzah, 2015, pp.
35-36).

Rama Djati's explanation of Ulu-ulu shows that the myth that exists is not just a mere belief. There are some people who think that these myths only told to frighten them, but in reality they are not. This myth can really happen to humans who act ignorant towards the rules when dealing with nature.

\section{Principle of Simple Living and Harmony with Nature}

This principle teaches us to live balanced and side by side with nature. We are required to use nature sufficiently, not too much. According to Keraf (2010, p. 175), the principle of living simply and in harmony with nature emphasizes values, quality, a good way of life, and not wealth, facilities, and material standards. Related to this, in Sebuah Wilayah yang Tidak Ada di Google Earth, there is a 
character called Mak Lasmi who does not want her land to be taken over by Chevron. Mak Lasmi has been given the mandate by her husband to continue to look after the house and the land they have. Even though Mak Lasmi was in an urgent situation, she was not permitted to sell her land.

"Iya, tenang saja. Tapi mengapa kau sangat berkeras untuk menolak perusahaan Amerika itu, Lasmi? Bukankah seperti kata banyak orang itu akan menguntungkan?

"Pertama, saya tak percaya tentang keuntungan itu, Ki. Kedua, kalaupun menguntungkan saya tak tertarik. Karena lahan saya di Desa Patulungan ini adalah peninggalan almarhum suami saya, Kang Ridwan. Beliaulah penyelamat hidup saya, yang menyayangi saya setelah cinta saya hanya dipermainkan beberapa lelaki. Kang Ridwan amanat supaya rumah lahan dan lading tempat kami menjalani hidup bersama itu supaya jangan dijual." (Hamzah, 2015, p. 125)

Her love and gratitude to Kang Ridwan, her husband, were able to provide a strong determination for Mak Lasmi to continue to defend her land. The thing done by Mak Lasmi is not because she is aware of the environmental safety, but rather due to her personal interests. Nevertheless, Mak Lasmi has the same determination as the other community to continue to oppose the geothermal management. Mak Lasmi still needs the land to continue to survive. Mak Lasmi is not easily tempted by the lure of more profits, if the management is carried out. She just wants to live modestly and side by side with her fields while remembering the love of Kang Ridwan.

\section{Justice Principle}

Talking about the principle of justice in environmental ethics, it will inevitably intersect with government regulations governing the environmental policies. The minimum form the government can take is in the form of an invitation to preserve, care for, and preserve nature to its people. The role of the government in this case is very large, because it has the power to direct the community to actively protect the environment.

Hari ini kata-kata dari Sang Penguasa justru terdengar lebih manusiawi dari seorang budayawan dan rohaniawan sekalipun: "Kita ini kelak akan ditanam kembali ke tanah, maka selagi masih bisa, maka kita banyak menanam pohon demi kelestarian alam milik anak cucu kita" (Hamzah, 2015, p. 42).

The above quote was made by Mr. Aang as the Kuningan Regent in an environmental seminar at Bale Kambang. He, as a regional official, realized that he had a big role to invite seminar participants to always plant trees for the sake of ecosystem sustainability.

\section{Democracy Principle}

Democratic principles are very relevant in the environmental field, especially in relation to policy making in the environmental field that determines whether good or bad, whether or not damaged and polluted by the environment (Keraf, 2010, p. 179). The principle of democracy in the novel Sebuah Wilayah yang Tidak Ada di Google Earth appeared to its leaders, when Chevron's plan to manage the geothermal potential of Mount Ciremai. Various rejections have been made since the change in the status of Mount Ciremai to Mount Ciremai National Park. The change is assumed by the community as a silent step and gradually handed over to foreigners to be exploited.

"Jangan salahkan masyarakat kalau akhirnya mencurigai bahwa TNGC adalah sebuah modus silent step atau 'langkahlangkah hantu' untuk secara perlahan dan halus menghambarkan ikatan simbiosis mutualisme antara penduduk dengan gunungnya. Memisahkan warga dengan lahan tercinta. Lantas nanti secara bertahap lahan itu akan diserahkan pada pihak asing untuk dieksploitasi." (Hamzah, 2015, p. 233)

Suspicion felt by the community then pushed them to continue to express their aspirations of rejection of the management of geothermal potential. To fight for the rejection, the 
community and the Gempur NGO, nature lovers, Save Ciremai activists, and personal sympathizers discuss and find ways for the management to cancel it by continuing to trace the goals and impacts that they will have in the future.

\section{Moral Integrity Principle}

This principle requires public officials to have respectable moral attitudes and behaviors and uphold the morals that secure the public interest. Public officials are required not to abuse their power at the expense of society and the environment (Keraf, 2010: 182). In the novel Sebuah Wilayah yang Tidak Ada di Google Earth there are several abuses of power committed by the government and investors. The Kuningan regional government changed the status of Mount Ciremai to Mount Ciremai National Park which was suspected as a 'ghost step' to be exploited by foreign parties. The government gave permission to Chevron to carry out geothermal exploration of Mount Ciremai.

There is also logging done by a television companies to install Trembesi trees or television shelters and results in decreased water intensity in the surrounding area. However, the plan was cancelled because the Tree-Cutting Man, who was the intermediary for the purchase of the land, had seen a very large impact due to the felling of Kiara trees. Then, the Tree-Cutting Man invites Haji Kuswara Sastrapermana (investor) to replant in the Cilengkrang Valley.

Selain ditanami pohon Kiara pada bulan Maret tahun 2013, bukit itu ditanami kembali oleh Si Lelaki Penebang Pohon dan Haji Kuswara Sastrapermana, investor yang menggagalkan rencananya membuat shelter televisi di bukit itu, dengan Pohon Trembesi, pemberian dari Yayasan Munardo (sekarang Danjen Kopasus) atas fasilitas dari Kepala Sekretariat Presiden Bapak Nanang Djuana Priadi. Setelah ditanami pohon-pohon tersebut, mulai terlihat sedikit peningkatan debit mata air di sana (Hamzah, 2015, p. 288).
They realize that how much power or position they have, cannot act carelessly against nature.

\section{The Role of Characters in Environmental Preservation in Sebuah Wilayah yang Tidak Ada di Google Earth by Pandu Hamzah}

\section{Not Pro-Environment}

Characters who are not pro-environment in Sebuah Wilayah yang Tidak Ada di Google Earth were the Tree-Cutting Man, Chevron, and the Government. In the beginning, the TreeCutting Man did a non-environmental action, namely cutting down a giant Kiara tree located in the Cilengkrang Valley which resulted in a decrease in the intensity of water in the surrounding area. The Tree-Cutting Man is tempted by Jakarta money worth tens of millions to become a broker to buy land and cut down a large Kiara tree in Cilengkrang valley.

Kurang lebih dua bulan lalu aku menjadi calo pembelian tanah sekaligus menebang sebatang Pohon Kiara besar karena wilayah tersebut akan dibangun shelter pemancar televisi swasta yang dirintis Kang Haji Kuswara, seorang investor dari Jakarta. Aku tak menebang langsung, namun mengorderkannya ke temanku, Theodorus Sandi. Lokasinya di perbatasan antara Desa Palutungan dan Pajambon dekat ke objek wisata Lembah Cilengkrang (Hamzah, 2015, p. 39).

After logging Kiara tree, there was a drought in the spring. The drought indicates an ecosystem imbalance.

Environmental issues raised in Sebuah Wilayah yang Tidak Ada di Google Earth not only about cutting down trees but also about the geothermal exploration of Mount Ciremai by Chevron and the government.

Situasi mulai kacau. Ini diperparah dengan tiba-tiba status Gunung Ciremai diubah oleh seorang menteri nun jauh di sana, yang mungkin menginjak ke Gunung Ciremai pun tidak pernah, menjadi Taman Nasional Gunung Ciremai. Keputusan yang aneh 
karena ditandatangani hanya satu hari saja sebelum menteri tersebut habis masa jabatannya.

Ketetapan ini membuat warga kehilangan akses terhadap hutan; sumber penghidupan mereka yang telah turun-temurun menjadi sandaram. Keputusan ini juga seolah menghina; memposisikan warga sebagai sumber malapetaka dari Gunung Ciremai dan harus disingkirkan, padahal sebelum status TNGC (Taman Nasional Gunung Ciremai) itu diberlakukan, Ciremai sudah bagus dengan konsep PHBM (Pengelolaan Hutan Bersama Masyarakat) yang sangat partisipasif dan tidak memiskinkan (Hamzah, 2015, p. 231).

The takeover of Mount Ciremai by the government seemed to break the chain of mutualism between people and nature. The concept of PHBM is a model of forest management by involving the community which includes community institutions, mechanisms of cooperation within a partnership framework, and conflict management. However, with the change in status to the Gunung Ciremai National Park, the community could no longer contribute to the management of the forest because it would be fully managed by the government.

Over time, people heard rumours that Mount Ciremai would be exploited by an American company. The community began to suspect that the change in the status of Mount Ciremai, which was originally managed by the concept of PHBM to TNGC, was a manipulation step carried out by the government.

"Jangan salahkan masyarakat kalau akhirnya mencurigai bahwa TNGC adalah sebuah modus silent step atau 'langkahlangkah hantu' untuk secara perlahan dan halus menghambarkan ikatan simbiosis mutualisme antara penduduk dengan gunungnya. Memisahkan warga dengan lahan tercinta. Lantas nanti secara bertahap lahan itu akan diserahkan pada pihak asing untuk dieksploitasi." (Hamzah, 2015, p. 233)

In addition to manipulating the status change, the government also manipulates the completeness of the Environmental Impact Assessment. Initially, the community was invited to attend socialization from Chevron and the government, but instead it was used as an opportunity to lie to the community.

\section{Pro-Environment}

Pro-environmental figures in Sebuah Wilayah yang Tidak Ada di Google Earth are The Tree-cutting man, Zasu, Black, Gadia Ajag, Mother Bird Walik, Happiness Angel, Octaviany Kiara, Rama Djati Kusuma, Mak Lasmi, and Kinanti.

After cutting down the Kiara tree, The Tree-Cutting Man is haunted by Ulu-ulu. Therefore, the Tree-cutting Man was suggested by Pak Fadil to meet Rama to find out more about Ulu-ulu. The Tree-Cutting Man met with Rama Djati to ask for further information about the Ulu-ulu who had disturbed him. Rama explained that Ulu-ulu is a forest fighter who maintains and controls the springs. Not just anyone can see Ulu-ulu, only people who have sinned damage the nature of nature. From Rama's statement, the felling man was aware of his mistake, which had cut down a giant Kiara tree in the Cilengkrang Valley.

The Tree-Cutting Man realizes his mistake of cutting down a Kiara tree only for the installation of a television shelter. In his ascent, he met with Zasu, Octaviany Kiara, The Black, and Ajag Girl in the Forest of Prohibition of the Princess. While surrounding the campfire, they plan to replant Kiara trees so that the balance of the Mount Ciremai ecosystem is restored.

Harusnya kau melihat pemandangan senja hari kemarin manakala Si Penebang Pohon membawaku dari rumahnya dengan cara didekap khidmat. Gadis Ajag mengikuti dengan bertatih-tatih karena baru disembuhkan lukanya di kampung halamannya di pedalaman belantara Ciremai, Si Hitam yang berjalan paling depan dan paling semangat membawa cangkul, Kiara yang berseri-seri, Zasu yang berjalan tegap di belakang mereka dengan rambut yang berkebaran (Hamzah, 2015, p. 283). 
Kiara trees that had been cared for by the TreeCutting Man at home were able to make amends because the tree was hard to find and had a unique life cycle, so it was very lucky for the Tree-Cutting Man to take care of the tree. At first they did not know about the life cycle of the Kiara tree, but thanks to the Angels of Happiness and the Mother of the Walik, they were finally able to save the last Kiara tree in the region.

The arrival of Chevron, which will manage geothermal potential, makes people feel worried. The community feels that government policies that change the status of Mount Ciremai to a National Park and Chevron will exploit geothermal potential, as if separating the chain of mutualism between the local community and its nature (Primadhyta, 2015). Therefore, various rejections emerged from the. In this novel, people who refuse to be represented by the characters are Mak Lasmi, Kinanti, and Octaviany Kiara.

Environmental issues are the basic theme of Sebuah Wilayah yang Tidak Ada di Google Earth, historically inspired by conflicts between the communities around Mount Ciremai and the West Java government and PT Chevron who plans to explore the Mount Ceremai geothermal (Nugraha, 2015). As a result of this resistance, Chevron cancelled its project on Mount Ciremai,

\section{Conclusion}

Based on the results and discussion conducted Sebuah Wilayah yang Tidak Ada di Google Earth by Pandu Hamzah, some conclusions can be drawn as follows. First, the manifestation of environmental wisdom found nine principles, including (1) respect for nature; (2) the attitude of responsibility towards nature; (3) cosmic solidarity; (4) the principle of compassion and care for nature; (5) the principle of no harm; (6) the principle of living simply and in harmony with nature; (7) the principle of justice; (8) democratic principles; (9) the principle of moral integrity. Second, the role of figures in environmental preservation there are two categories found, among others, non-environmental figures and proliferative figures. Both have a difference in the amount of data that is quite far away, the character of the environment is more dominant than the non-environment. Prominent figures include, The Tree-Cutting Man, Rama Djati Kusuma, The Black, Mak Lasmi, Ajag Girl, Angel of Religion, Mother of Walik Bird, Zasu, Octaviany Kiara, Kinanti (Mama Kiara). Whereas the figures who did not proenvironment include, among other things, the Tree-Cutting Man who later based his actions on cutting down trees which was detrimental to nature, Chevron, and the government. This shows that Pandu Hamzah as the writer of Sebuah Wilayah yang Tidak Ada di Google Earth wants to invite the readers to be aware and care about the environment by giving examples through their characters who struggle to restore the balance of the ecosystem and dare to reject what is perceived as detrimental to the environment.

\section{References}

Alviya. (2006). Penetapan Hutan Lindung Gunung Ceremai Menjadi Taman Nasional dan Dampaknya bagi Masyarakat Sekitar Kawasan. E-Journal Aalisis Kebijakan Kehutanan, 3(2).

Hamzah, Pandu. (2015). Sebuah Wilayah yang Tidak Ada di Google Earth. Tangerang: Lentera Hati.

Humas KLHK. (2019). "Sinergitas Lintas Sektor Dukung Penyelamatan Danau Prioritas Nasional." Retrieved 3 April 2019 from http://www.menlhk.go.id/ site/single_post/1979.

https://ekonomi.bisnis.com/read/20140421/ 44/221085/masyarakat-gunungciremai-tolak-pltp

Keraf, Sonny A. (2010). Etika Lingkungan Hidup (Revised edition). Jakarta: Kompas Publisher.

Nugraha, Indra. (2015). "Chevron Batalkan Proyek Geotheemal Ciremai, Mengapa?”. 
Retrieved 25 April 2019 from https:// www.mongabay.co.id/2015/01/23/che vron-batalkan-proyek-geothermalciremai-mengapa/

Primadhyta, Safyra. (2015). "Ditolak Warga, Chevron Lepas Proyek Pembangkit Gunung Ciremai." Retrieved 10 August 2019 from https://www.cnnindonesia. com/ekonomi/20150123161528-85-26 909/ditolak-warga-chevron-lepas-proye k-pembangkit-gunung-ciremaih.

Sukmawan, Sony. (2015). Sastra Lingkungan: Sastra Lisan Jawa dalam Perspektif Ekokritik Sastra. Malang: UB Press.

(2016). Ekokritik Sastra: Menanggap Sasmita Arcadia. Malang: UB Press.

Susilo, Rachmad K. Dwi. (2012). Sosiologi Lingkungan dan Sumber Daya Alam. Yogyakarta: Ar-Ruzz Media.

Warren, K. J. (2011). An Ecofeminist Philosophical Perspective of Anthny Weston's the Incompleat EcoPhilosopher. Etics, Politicy, \& Enviromental, 14(1), 103-111. doi: $10.1080 / 21550085.2011 .561603$.

Wiyatmi, dkk. (2019). Ekofeminisme: Kritik Sastra Berwawasan Ekologis dan Feminis. Yogyakarta: Cantrik Pustaka. Second edition. 